\title{
顎変形症の臨床診断に関する全国調査
}

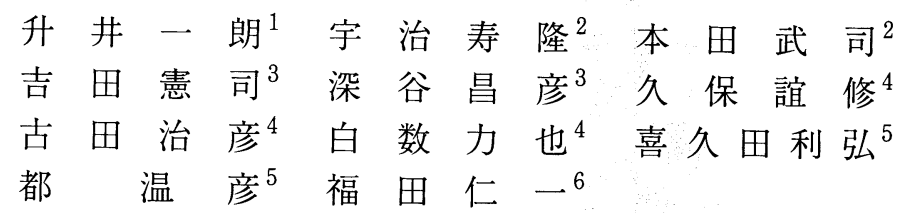

\section{Survey on Japanese Terminology for the Clinical Diagnosis of Maxillofacial Deformities}

\author{
ICHIRo MASUI ${ }^{1}$, TOSHITAKA UJI ${ }^{2}$, TAKESHI HONDA ${ }^{2}$, \\ Kenji YOSHIDA ${ }^{3}$, Masahiko FUKAYA ${ }^{3}$, YoshinOBU KUBO ${ }^{4}$, \\ HARUhiko FURUTA ${ }^{4}$, RikiYa SHIRASU ${ }^{4}$, TOSHIHIRO KIKUTA ${ }^{5}$, \\ HARUHIKO MIYAKO ${ }^{5}$ and JINICHI FUKUDA ${ }^{6}$
}

\begin{abstract}
The diagnosis of maxillofacial deformities may consist of two aspects : one is primary diagnosis which may be defined as the clinical diagnosis of facial morphology and occlusion based on clinical inspection, the other is secondary diagnosis based on cephalometric analysis, model analysis and so on. Since the chief objective of orthognathic surgery is improvement of facial disharmong and malocclusion, the clinical diagnosis has much to do with the treatment planning and its result. However, clinical diagnosis of the facial morphology greatly depends on the clinician's subjectivity, and it is considered that a great variety of the terminology would be used in the clinical diagnosis.

The purpose of this study was to survey the terminology for clinical diagnosis used by OMF surgeons and orthodontists. The facial pictures (frontal and lateral views) and intraoral pictures in centric occlusion (frontal and lateral views) of four patients with maxillofacial deformity were sent to orthodontists and oral and maxillofacial (OMF) surgeons who belonged to a dental school or a medical school in Japan. They were simply asked to make a clinical diagnosis for each patient. Seventy-nine OMF surgeons and 16 orthodontists replied. The returned diagnoses were subjected to statistical analysis and the results were as follows:
\end{abstract}

1 福岡医療短期大学

2 福岡歯科大学口腔外科学第 2 講座 (主任: 本田武司教授)

3 愛知学院大学歯学部口腔外科学第 1 講座 (主任代行 : 河合 幹教授)

4 大阪歯科大学口腔外科学第 1 講座 (主任 : 白数力也教授)

5 福岡大学医学部歯科口腔外科学講座 (主任 : 都 温彦教授)

6 九州歯科大学口腔外科学第 1 講座 (主任 : 福田仁一教授)

1 Fukuoka College of Health Sciences

2 Second Department of Oral and Maxillofacial Surgery, Fukuoka Dental College (Chief: Prof. Takeshi HONDA)

3 The 1st Department of Oral and Maxillofacial Surgery, School of Dentistry, Aichi-Gakuin University (Acting chief: Prof. Tsuyoshi KAWAI)

4 First Department of Oral and Maxillofacial Surgery, Osaka Dental College (Chief : Prof. Rikiya SHIRASU)

${ }_{5}^{5}$ Department of Oral and Maxillofacial Surgery, School of Medicine, Fukuoka University (Chief: Prof. Haruhiko MIYAKO)

${ }^{6}$ First Department of Oral and Maxillofacial Surgery, Kyushu Dental College (Chief: Prof. Jinichi FUKUDA) 
1) The diagnostic terminology was categorized into six groups: (1) the generic term, (2) prognathism of maxilla or mandible, (3) symmetry, (4) facial height, (5) occlusion, and (6) others.

2) There was a great variety of Japanese terminology applied to the same symptom. It is desired that the diagnostic terminology be standardized and unified.

3) From the diagnoses of facial morphology, convexity of the lower third of the face in the profile view was commonly recognized, but middle-third anteroposterior deficiency, facial asymmetry in the frontal view or difference in facial height were generally not recognized except for a remarkable case.

Key words : Maxillofacial Deformity (顎顔面変形症), Diagnosis (診断), Terminology (用語) [Received Jun. 16, 1997]

\section{緒言}

顎変形症の診断は，顔面形態や咬合の臨床視診 に基づく臨床診断と, 頭部X線規格写真分析（以 下セファロ分析）や顎態模型分析などによる 2 次 的診断の 2 つに大別することができる。一般に顎 変形症の診断では, 両者を総合して最終的な診断 名がつけられるが, 臨床視診での顔面変形や不正 咬合の症候名がそのまま診断名に適用されること が多い1。

顎変形症の治療目的は, 顔貌および咬合の改善 と, それに伴う機能的・心理的改善にあるため, 顔面形態と咬合の診断が治療方針の決定や治療結 果に対して重要な意味合いをもつことは言うまで もない。しかし, 顔面形態の診断に絶対的基準を 設けることは困難で, 主観的判断に依存する部分 が大きい(2-4)ことも事実である。また現状では, 診 断名用語やその適用に共通の解釈が見当たらない ため, 同一症例でも診断者が変われば異なる診断 名がつけられることがある ${ }^{2,5)} 。$

そこで, 外科的矯正治療に携わる口腔外科医と 矯正歯科医に, 顎変形症例の写真を提示して, ど のような臨床診断名がつけられるかを調査し, 使 用される診断名用語の種類と, その適用の実態を 明らかにすることを目的として, アンケート調查 を行った。

\section{調查対象と方法}

調査対象は全国の大学歯学部, 医学部に所属す る矯正歯科医と口腔外科医である。但し, 著者ら が所属する講座の口腔外科医および同じ大学の矯 正歯科医は, 調査対象から除外した。

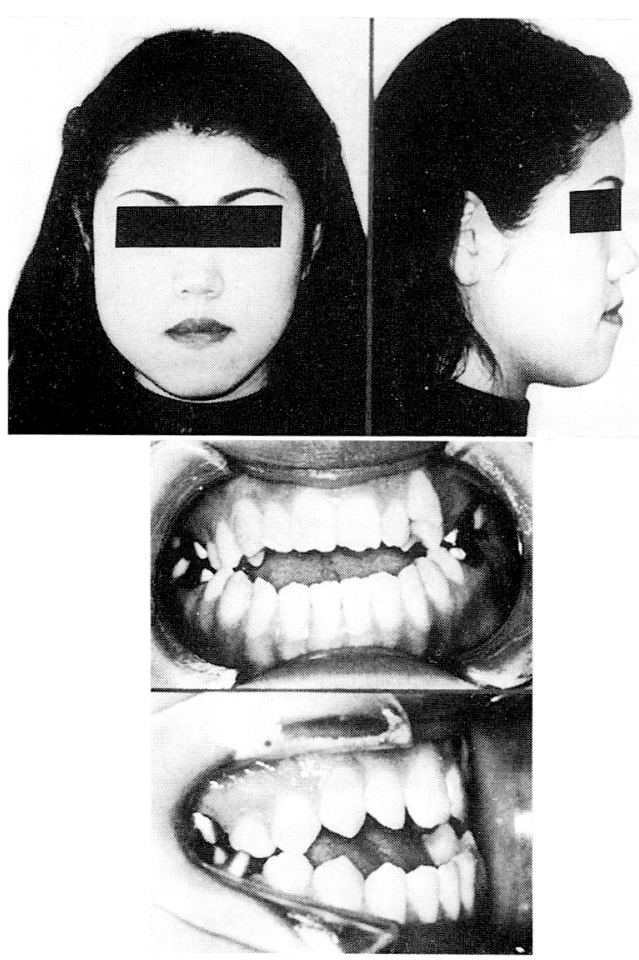

Fig. 1 Facial and intra-oral photographs of Case 1

資料は顎変形症患者 4 名の, 正面および右側面 顔貌写真と中心咬合位での正面㧍よび右側面口腔 内写真 (Fig. 1〜4) である。アンケートは顔貌写 真と口腔内写真から, 各症例に適当と思われる臨 床診断名を, 複数併記も可として記人してもらい, その表記方法については特に指定しなかった。ま た, 回答者の外科的矯正治療に携わる年数と経験 症例数を記入してもらった。資料の送付は1997年 3 月から 5 月の期間に，インターネットを利用し た電子メールあるいは郵便で行い，両者ともカラ 


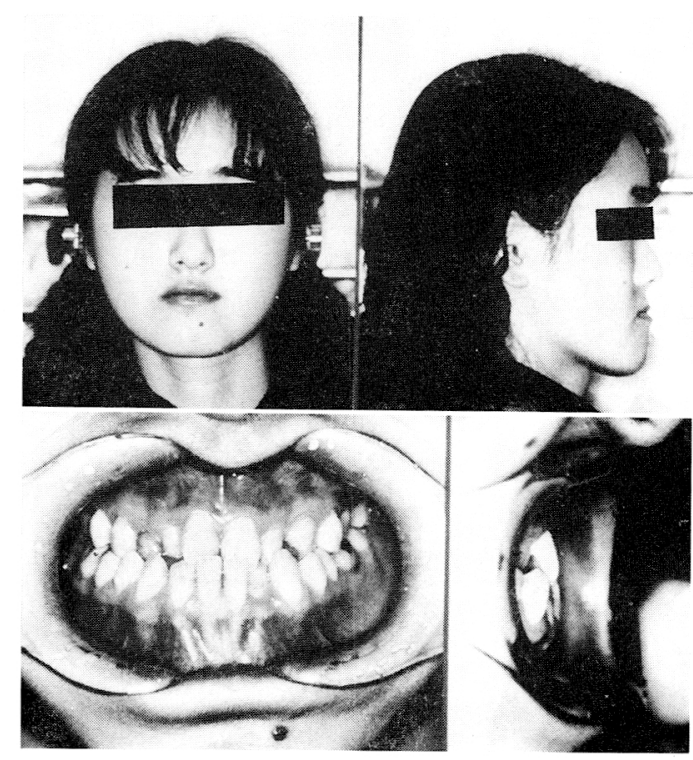

Fig. 2 Facial and intra-oral photographs of Case 2

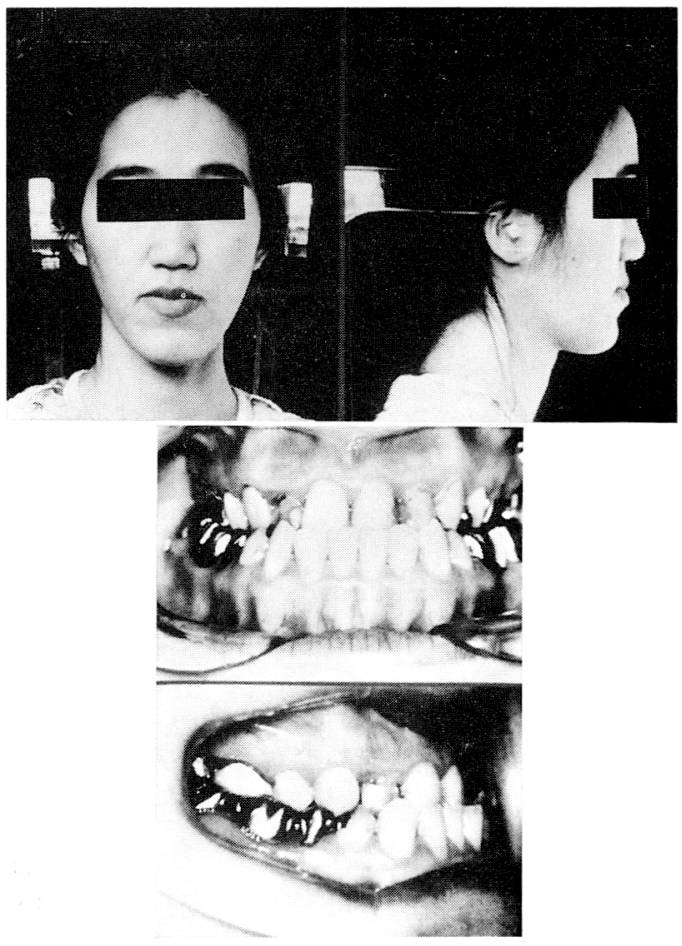

Fig. 3 Facial and intra-oral photographs of Case 3

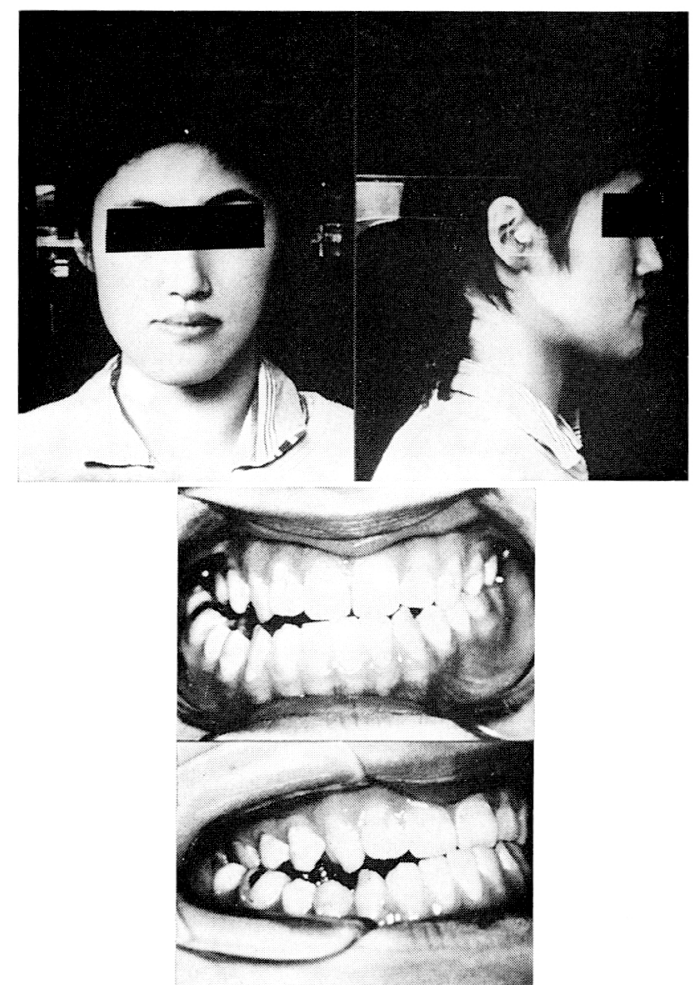

Fig, 4 Facial and intra oral photographs of Case 4

一写真を送付した。

\section{結 果}

1. 回答施設と回答数 (Table 1)

アンケートの回答は歯学部口腔外科 22 施設，歯 学部矯正歯科 12 施設, 医学部口腔外科 21 施設, 医 学部矯正歯科 1 施設の合計55施設から得られた。 回答数は合計95通で，このうち電子メールによる ものは27通，残り68通は郵送による返信であった。 科別にみると口腔外科から 79 通 $(83.2 \%)$, 矯正 歯科から16通 $(16.8 \%$ ) で, その比は約 5：1 で あった。

2. 回答者の経験年数 (Table 2)

回答者の外科的矯正治療に携わる経験年数は, 5 年以下が 22 名 $(23.2 \%) ， 6$ 年から 10 年が 28 名 (29.5\%)，11年から 15年が22名 $(23.2 \%) ， 16$ 年 から 20 年が14名 (14.7\%)，21年以上が 7 名 (7.4 \%)，記入なしが 2 名 $(2.1 \%$ ）であった。口腔外 科医と矯正歯科医間に，回答者数では開きがある 
Table 1 Number of replies

\begin{tabular}{l|c|c|c|c}
\hline \multicolumn{2}{c|}{ Institution } & OMF surgeon & Orthodontist & Total \\
\hline detal* $^{*} 25$ & 22 & 12 & 34 \\
\hline medical** $^{*} 21$ & 20 & 1 & 21 \\
\hline Sum & 46 & 42 & 13 & 55 \\
\hline \hline Total & $79(83.2 \%)$ & $16(16.8 \%)$ & $95(100 \%)$ \\
\hline
\end{tabular}

* : belong to dental school **: belong to medical school

Table 2 Comparison of experience years of between OMF surgeons and Orthodontists

\begin{tabular}{r|c|c|c}
\hline experiences & OMF surgeon & Orthodontist & Sum (\%) \\
\hline under 5 years & $20(25.3)$ & $2(12.5)$ & $22(23.2)$ \\
6 to 10 years & $24(30.4)$ & $4(25.0)$ & $28(29.5)$ \\
11 to 15 years & $17(21.5)$ & $5(31.3)$ & $22(23.2)$ \\
16 to 20 years & $11(13.9)$ & $3(18.6)$ & $14(14.7)$ \\
over 21 years & $6(7.6)$ & $1(6.3)$ & $7(7.4)$ \\
not mentioned & $1(1.3)$ & $1(6.3)$ & $2(2.1)$ \\
\hline Total & $79(100 \%)$ & $16(100 \%)$ & $95(100 \%)$ \\
\hline
\end{tabular}

Table 3 Classification of writing forms of clinical diagnosis

\begin{tabular}{ll}
\hline \multicolumn{1}{c}{ Writing form } & \multicolumn{1}{c}{ Example } \\
\hline Single form & Mandibular prognathism \\
Compound form of multiple terms & Asymmetric mandibular prognathism \\
Parallel form of multiple terms & $\$ 1$ Open bite $\$ 2$ Angle class III \\
& \#3 Mandibular prognathism \\
\hline
\end{tabular}

が，経験年数別割合はほぼ同じであった。

3. 診断名と表記形式の分類 (Table 3)

診断名の表記形式を指定しなかったため，得ら れた回答は様々な表記形式があった。これらを以 下の 3 タイプに分類した。

1）単独の診断名を表記したもの。

2）複数の診断名を複合表記したもの，例えば 「開咬を伴う下顎前突症」や「非対称性下顎前突」 など。

3）複数の診断名を並列表記したもの。

2）の複合表記では診断名の集計が困難である ため，例えば「開咬を伴う下顎前突症」であれば 「開咬」と「下顎前突症」の並列表記に変更して, 以下の集計を行った。

4. 診断名用語のカテゴリー分類
回答された診断名用語を意味の上から大別する と, (1)「顎変形症」や「顎顔面変形症」などの総 称を表す用語，(2)上顎・下顎の前突度を表す用語， (3)正面顔貌の対称・非対称を表す用語, (4)顔面の 高さ（長さ）の異常を表す用語，(5)咬合所見を表 す用語, (6) その他の用語の 6 つのカテゴリーに分 類された（Table 4)。

この分類に従って, 症例 1 に使用された用語を 集計すると, 総称名 2 種類, 上顎 -下顎の前突度 を表す用語 12 種類, 正面顔貌の対称・非対称を表 す用語 12 種類, 顔面の高さの異常を表す用語 3 種 類, 咬合所見を表す用語 15 種類, 咬筋肥大症な ど，その他の用語 4 種類で，合計 48 種類であった (Table 5)。

\section{5. 臨床診断名の総括}


Table 4 Category of Japanese terminology applied to the diagnosis of maxillofacial deformity

\begin{tabular}{|c|c|}
\hline Category & examples of Japanese term \\
\hline 1. Generic term & 顎変形症, 䫟顔面変形症 etc. \\
\hline $\begin{array}{l}\text { 2. Prognathism of maxilla or } \\
\text { mandible }\end{array}$ & 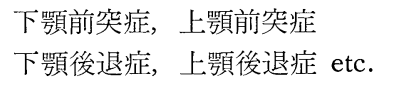 \\
\hline 3. Asymmetry of frontal face & 顔面非対称，下額偏位 ets. \\
\hline 4. Facial Height & 長顔症，短顔症 etc. \\
\hline 5. Occlusion & 開咬, 反対咬合, 交叉咬合 etc. \\
\hline 6. Others & 咬筋肥大症 大オトガイ症 etc. \\
\hline
\end{tabular}

回答された診断名のらち，同義と考えられる診 断名は回答数が多い用語にまとめ, 各症例の診断 名を総括した。

1）症例 1 亿対する臨床診断名の総括

症例 1 の診断名で多かったのは開咬症の $84.2 \%$, 下顎前突症の $69.5 \%$ ，顔面非対称の $34.7 \%$ ，咬筋 肥大症の $14.7 \%$ ，前歯部開咬の $13.7 \%$ であった。 開咬症と前歯部開咬を合わせると約 $98 \%$ となり, ほぼ全員が開咬を臨床診断名に挙げていた。矯正 歯科医と口腔外科医の回答を比較すると，下顮前 突症, 顔面非対称, 開咬症, 前歯部開咬症につい ては両者ともほぼ同じ比率であったが，咬筫肥大 症は口腔外科医にのみみられた（Table 6)。

2) 症例 2 亿対寸る臨床診断名の総括

下顎前突症が圧倒的に多く $87.4 \%$ 占め, 次に 上顎後退症の $24.2 \%$, 叢生の $18.9 \%$, 反対咬合の $12.6 \%$ の順であった。下顎前突症の回答は矯正歯 科医と口腔外科医間に差はないが，上顎後退症は 口腔外科医が $26.6 \%$ に対して矯正歯科医では 12.5 \%であった。叢生，反対咬合など咬合所見に関す る診断名は, 矯正歯科医にやや多い傾向を認めた (Table 7)。

3）症例 3 に対する臨床診断名の総括

下顎前突症の回答が $64.2 \%$ で最も多く, 口腔外 科医は $62 \%$ ，矯正歯科医は $75 \%$ であった。下頡前 突症は前者にやや少ないが，その代わりに上顎後 退症を挙げた口腔外科医の割合は, 矯正歯科医の 3 倍以上であった。また，長顔症を挙げたのは口 腔外科医が $13.9 \%$, 矯正歯科医が $25 \%$ で, 両者と もあまり多くはなかった（Table 8)。

\section{4）症例 4 亿対する臨床診断名の総括}

顔面非対称が $87.4 \%$ と最も多く, 次に下顎前突 症 $66.3 \%$ ，交叉咬合 $33.7 \%$, 開咬症 $30.5 \%$ の順で， 矯正歯科医々口腔外科医はほぼ同じ割合であった。 また咬合所見の診断名も, 両者とも類似していた (Table 9)。

\section{考察}

本研究では, 顎変形症患者の顔面および咬合の 臨床視診に基づく診断を臨床診断と呼ぶことにし て, 臨床例の顔面および口腔内写真を提示して, 臨床診断名を問らアンケート調査を行った。回答 数は口腔外科医から79通, 矯正歯科医から16通で 合計95通であった。矯正歯科医からの回答が少な かった理由は，施設数が口腔外科より少ないこと もあるが，数人の矯正歯科医からの問い合わせの 中で，「セファ口分析の資料が必要」とのコメン トがあったことから推察して, 顔面と口腔内写真 のみでは診断をつけられないと判断されたのかも 知れない。顔面形態の診断は, 顔面各部の顔面全 体の中での調和・不調和を認知して特徴抽出を行 い，それを各診断者がイメージとして持っている 症型と照合して行われると考えられる4)。したが って顔面形態の診断には主観的要素が含まれるた め, 診断名をつける際には, 再現性のあるセファ 口分析が優先される傾向があると推測される。し かし，顔面形態の診断とセファロ分析による診断 とが必ずしも一致するとは限らない。飯塚 ${ }^{6)}$ は 「顎変形症患者の治療目的はセファ口分析の值を 正常にすることではない」と述べ, 顔面形態の診 
Table 5 Japanese terminology applied to the sample Case 1

\begin{tabular}{|c|c|c|c|c|}
\hline 1. & Generic term $\quad(2$ kind $)$ & & & \\
\hline & 顎顔面変形症 & 1 & 顎変形症 & 3 \\
\hline \multirow[t]{7}{*}{2.} & Prognathism of maxilla or & $r$ mandible & (12 kind) & \\
\hline & 下顎前乫症 & $36(37.9)$ & 対称性骨格性下顎前突症 & 1 \\
\hline & 下蘱前突 & $10(10.5)$ & Mandibular prognathism & 1 \\
\hline & 下顎骨前突症 & 1 & 骨格性反対咬合 & 1 \\
\hline & 骨格性下顎前突症 & $8(8.4)$ & Skeletal class III & 2 \\
\hline & 骨格性下顎前突 & $3(3.2)$ & 骨格性 3 級不正咬合 & 1 \\
\hline & 上顎後退症 & $3(3.2)$ & 上顎劣成長 & 2 \\
\hline \multirow[t]{7}{*}{3.} & Asymmetry $\quad(12$ kinds $)$ & & & \\
\hline & 顔面非対称 & $17(17.9)$ & 非対称性顎変形症 & 1 \\
\hline & 顔面非対称症 & 1 & 下顎非対称 & $4(4.2)$ \\
\hline & 顔面左右非対称 & 1 & 上下顎非対称 & 1 \\
\hline & 中・下顔面非対称 & 1 & 下顎骨偏位 & 1 \\
\hline & 正貌非対称 & 1 & Asymmetry & 1 \\
\hline & 左右非対称 & 1 & 非対称（「を伴う～」) & $4(4.2)$ \\
\hline \multirow[t]{3}{*}{4.} & Facial Height (3 kinds) & & & \\
\hline & Disproportion (vertical) & 1 & 長顔症 & 1 \\
\hline & Long face & 1 & & \\
\hline \multirow[t]{9}{*}{5.} & (15 kinds) & & & \\
\hline & 開咬症 & $32(33.7)$ & 犬歯低位唇側転位 & 3 \\
\hline & 開咬（「を伴ら〜」を含む) & $40(42.1)$ & 叢生 & 2 \\
\hline & 骨格性開咬 & 4 & 上頢歯列狭窄症 & 1 \\
\hline & Skeletal open bite & 1 & 臼歯部交叉咬合 & 1 \\
\hline & Open bite & 2 & 反対咬合 & $6(6.3)$ \\
\hline & 前歯部開咬 & $8(8.4)$ & Angle class III & $8(8.4)$ \\
\hline & 前歯部開咬症 & 5 & & \\
\hline & Anterior open bite & 1 & & \\
\hline \multirow[t]{3}{*}{6.} & (4 kind) & & & \\
\hline & 咬筋肥大症 & $8(8.4)$ & 咬筋肥大疑い & 2 \\
\hline & 咬笳肥大症疑い & $4(4.2)$ & 煩部軟組織腫脹 & 1 \\
\hline
\end{tabular}

断の重要性を強調している。また, 橋本ら ${ }^{1)}$, 中 村ら ${ }^{51}$ は顔面形態の診断表記法試案を報告し，さ らに久保ら ${ }^{2)}$ は顔面形態分類チャートを試作し， 顔面形態分類の統一化と診断の再現性の向上を謀 っている ${ }^{4)}$ 。著者らも，咬合と顔面骨格の診断の みならず，顔面形態の診断が治療方針に影響を与 えると考え, これらの見解と一致する。

さて, 本調査の目的は顎変形症患者に対する臨 床診断の実態を明らかにすることである。そこで,
資料に用いた症例は本邦では発現頻度の高い下顎 前突を呈する症例で，これに中顔面の宿凹感や正 貌の非対称，顔面高さの不調和，あるいは開咬や 交叉咬合が異なる程度に合併した 4 症例を選択し た。これらに対して回答された診断名から，どの ような診断名用語が使用されるか, また各症例に 対する診断名の集計から, 顔面形態の異常や不正 咬合が，どの程度認知されるかを検討した。

回答された診断名は実にさまざまで, 症例 1 に 
Table 6 Clinical diagnoses applied to the sample Case 1.

Each diagnostic terms in the table are compre-

hensive of the similar meaning terms.

\begin{tabular}{lccc}
\hline \multicolumn{1}{c}{ Diagnosis } & $\begin{array}{c}\text { OMF surgeon } \\
70(100 \%)\end{array}$ & $\begin{array}{c}\text { Orthodontist } \\
16(100 \%)\end{array}$ & $\begin{array}{c}\text { total } \\
\end{array}$ \\
\hline Mand. Prognathism & $55(69.6)$ & $11(68.8)$ & $66(69.5)$ \\
Max. Retrognathism & $5(6.3)$ & 0 & $5(5.3)$ \\
\hline Facial Asymmetry & $28(35.4)$ & $5(31.3)$ & $33(34.7)$ \\
\hline Long Face & $1(1.3)$ & $1(6.3)$ & $2(2.1)$ \\
\hline Open bite & $66(83.5)$ & $14(87.5)$ & $80(84.2)$ \\
Anterior open bite & $11(13.9)$ & $2(12.5)$ & $13(13.7)$ \\
Angle class III & $4(5.1)$ & $2(12.5)$ & $6(6.3)$ \\
Others & $1(1.3)$ & $1(1.3)$ & $2(2.1)$ \\
\hline Masseter hypertrophy & $14(17.7)$ & 0 & $14(14.7)$ \\
\hline
\end{tabular}

Table 7 Clinical diagnoses applied to the sample Case 2. Each diagnostic terms in the table are comprehensive of the similar meaning terms.

\begin{tabular}{lccc}
\hline \multicolumn{1}{c}{ Diagnosis } & $\begin{array}{c}\text { OMF surgeon } \\
79(100 \%)\end{array}$ & $\begin{array}{c}\text { Orthodontist } \\
16(100 \%)\end{array}$ & $\begin{array}{c}\text { total } \\
\end{array}$ \\
\hline Mand. Prognathism & $70(88.6)$ & $13(81.3)$ & $83(87.4)$ \\
Max. Retrognathism & $21(26.6)$ & $2(12.5)$ & $23(24.2)$ \\
Max. Prognathism & $1(1.3)$ & 0 & $1(1.1)$ \\
\hline Crowding & $13(16.5)$ & $5(31.3)$ & $18(18.9)$ \\
Cross bite & $9(11.4)$ & $3(18.8)$ & $12(12.6)$ \\
Anterior cross bite & $1(1.3)$ & $3(18.8)$ & $4(4.2)$ \\
Angle class III & $2(2.5)$ & $1(6.3)$ & $3(3.2)$ \\
Others & $5(6.3)$ & $1(6.3)$ & $6(6.3)$ \\
\hline
\end{tabular}

対して 48種類の診断名があった。これらを大別す ると, Table 4 に示す 6 つのカテゴリーに分類さ れたが，各カテゴリーの中で同義語と考えられる 用語も，診断者により異なっていた。例えば，症 例 1 亿使用された「下䇗前突症」を表す用語は, 下顎前突症, 下顎前突, 下顎骨前突症, 骨格性下 䫟前突症，骨格性下顎前突，対称性骨格性下顎前 突症, Mandibular prognathism, 骨格性反対咬合, Skeletal class III, 骨格性 3 級不正咬合の 10 種類 であった。また,「顔面非対称」を表す用語は, 顔 面非対称, 顔面非対称症, 中-下顔面非対称, 正 貌非対称, 左右非対称, 非対称性顎変形症, 下顎 非対称，上下顎非対称，下㚰骨偏位，Asymme$\mathrm{rty}$, 非対称 (を伴う〜) の12種類, 咬合所見のう
ち「開咬」を表す用語は，開咬症，開咬，骨格性 開咬, Skeletal open bite, Open bite, 前歯部開 咬, 前歯部開咬症, Anterior open bite の 8 種 類であった。このように同一症例に対して, 診断 者により異なる用語が使用されることは, 症例や 研究報告を比較する上で障害となるため, 共通の 用語が使用されることが望ましい。今後, 本学会 において検討されることを期待したい。

各症例に対する診断名の集計から, 顔面形態の 異常や不正咬合が，どの程度認知されたかを知る ことができる。上・下顎の前突度に関しては，4 症例とも「下顎前突症」が $65 \%$ 以上で高頻度にみ られた。しかし，オトガイ部の前突がなく中顔面 に軽度の陥凹感を認める症例 3 に対して,「上顎 
Table 8 Clinical diagnoses applied to the sample Case 3. Each diagnostic terms in the table are comprehensive of the similar meaning terms.

\begin{tabular}{lccc}
\hline Diagnosis & $\begin{array}{c}\text { OMF surgeon } \\
79(100 \%)\end{array}$ & $\begin{array}{c}\text { Orthodontist } \\
16(100 \%)\end{array}$ & $\begin{array}{c}\text { total } \\
\text { (100\%) }\end{array}$ \\
\hline Mand. Prognathism & $49(62.0)$ & $12(75.0)$ & $61(64.2)$ \\
Max. Retrognathism & $34(43.0)$ & $2(12.5)$ & $36(37.9)$ \\
\hline Facial Asymmetry & $12(15.2)$ & $4(25.0)$ & $16(16.8)$ \\
\hline Long Face & $11(13.9)$ & $4(25.0)$ & $15(15.8)$ \\
\hline Anterior cross bite & $15(19.0)$ & $7(43.8)$ & $22(23.2)$ \\
Angle class III & $4(5.1)$ & $2(12.5)$ & $6(6.3)$ \\
Lateral cross bite & $3(3.8)$ & $2(12.5)$ & $5(5.3)$ \\
Crowding & $3(3.8)$ & 0 & $3(3.2)$ \\
\hline Chin Excess & $1(1.3)$ & 0 & $1(1.1)$ \\
\hline
\end{tabular}

Table 9 Clinical diagnoses applied to the sample Case 4 . Each diagnostic terms in the table are comprehensive of the similar meaning terms.

\begin{tabular}{|c|c|c|c|}
\hline Diagnosis & $\begin{array}{c}\text { OMF surgeon } \\
79(100 \%)\end{array}$ & $\begin{array}{l}\text { Orthodontist } \\
16(100 \%)\end{array}$ & $\begin{array}{c}\text { total } \\
95(100 \%)\end{array}$ \\
\hline Mand. Prognathism & $53(67.1)$ & $10(62.5)$ & $63(66.3)$ \\
\hline Max. Retrognathism & $9(11.4)$ & $1(6.3)$ & $10(10.5)$ \\
\hline Facial Asymetry & $70(88.6)$ & $13(81.3)$ & $83(87.4)$ \\
\hline Lateral cross bite & $25(31.6)$ & $7(43.8)$ & $32(33.7)$ \\
\hline Open bite & $23(29.1)$ & $6(37.5)$ & $29(30.5)$ \\
\hline Angle class III & $4(5.1)$ & $2(12.5)$ & $6(6.3)$ \\
\hline Edge-to-edge bite & $3(3.8)$ & $1(6.3)$ & $4(4.3)$ \\
\hline Others & $2(2.5)$ & 0 & $2(2.1)$ \\
\hline
\end{tabular}

後退症」は全体で $37.9 \%$ と少なく, 矯正歯科医で は $12.5 \%$ とさらに少なかった。「上顎後退症」は， 上下の顎関係から「相対的下顎前突症」とする見 方もあるため, 中顔面の陥凹感が認知されても， 「上顎後退症」を挙げるものは少なかったと考光 られる。

正貌の対称・非対称に関しては，左右眼球の高 さの不一致と下顎の著明な右側偏位が見られる症 例 4 に対して, 回答者の $87.4 \%$ が 「顔面非対称」 を挙げた。しかし，オトガイ部の偏位がなく，右 側下䇗角部の膨隆と人中の傾斜が見られる症例 1 では $34.7 \%$ ，オトガイ部の軽度左側偏位が見られ る症例 3 では $16.8 \%$ が「顔面非対称」を挙げたに 過ぎなかった。つまり，顔面の非対称の認知は，
下顎の偏位が注目され易く，下顎角部の非対称や 軽度の下顎偏位では「顔面非対称」が診断に挙げ られることは少ないと思われる。また, 症例 1 に 対して，「咬筇肥大症」は口腔外科医にのみみら れたことから，同診断名は顎変形症の診断名とし て未だ普及していないと思われる。

顔面の高さは, 側貌における上・中・下顔面の 高さと，正貌における顔面の高さと幅の不調和に より認知されると思われる。症例 3 は上顔面に対 して中・下顔面が長く, 正貌でも過長感が見られ るが，「長顔症」は全体の $15.8 \%$ に過ぎなかった。 このことょり, 顔面高さの異常は認知され難く, また「長顔症」の診断名は普及には至っていない と考光られ。 
Table 10 Relation between years of experience and number of diagnoses

\begin{tabular}{|c|c|c|c|c|c|c|c|c|c|}
\hline \multirow{2}{*}{\multicolumn{2}{|c|}{ years of experiences }} & \multicolumn{7}{|c|}{ Number of diagnoses } & \multirow[b]{2}{*}{ Sum } \\
\hline & & 1 & 2 & 3 & 4 & 5 & 6 & 7 & \\
\hline \multirow[t]{6}{*}{ Caye 1} & under 5 years & 4 & 11 & 5 & 2 & 0 & 0 & 0 & 22 \\
\hline & 6 to 10 years & 4 & 14 & 7 & 2 & 1 & 0 & 0 & 28 \\
\hline & 11 to 15 years & 4 & 10 & 5 & 2 & 1 & 0 & 0 & 22 \\
\hline & 16 to 20 years & 1 & 4 & 5 & 3 & 1 & 0 & 0 & 14 \\
\hline & over 21 years & 1 & 1 & 4 & 0 & 1 & 0 & 0 & 7 \\
\hline & not mentioned & 0 & 1 & 1 & 0 & 0 & 0 & 0 & 2 \\
\hline & Sum & 14 & 40 & 26 & 9 & 4 & 0 & 0 & 95 \\
\hline \multirow[t]{6}{*}{ Case 2} & under 5 years & 13 & 9 & 0 & 0 & 0 & 0 & 0 & 22 \\
\hline & 6 to 10 years & 15 & 12 & 1 & 0 & 0 & 0 & 0 & 28 \\
\hline & 11 to 15 years & 16 & 4 & 1 & 1 & 0 & 0 & 0 & 22 \\
\hline & 16 to 20 years & 4 & 5 & 4 & 1 & 0 & 0 & 0 & 14 \\
\hline & over 21 years & 2 & 5 & 0 & 0 & 0 & 0 & 0 & 7 \\
\hline & not mentioned & 1 & 1 & 0 & 0 & 0 & 0 & 0 & 2 \\
\hline & Sum & 51 & 36 & 6 & 2 & 0 & 0 & 0 & 95 \\
\hline \multirow[t]{6}{*}{ Case 3} & under 5 years & 13 & 9 & 0 & 0 & 0 & 0 & 0 & 22 \\
\hline & 6 to 10 years & 13 & 11 & 4 & 0 & 0 & 0 & 0 & 28 \\
\hline & 11 to 15 years & 13 & 7 & 2 & 0 & 0 & 0 & 0 & 22 \\
\hline & 16 to 20 years & 3 & 4 & 5 & 1 & 0 & 0 & 1 & 14 \\
\hline & over 21 years & 1 & 5 & 1 & 0 & 0 & 0 & 0 & 7 \\
\hline & not mentioned & 0 & 2 & 0 & 0 & 0 & 0 & 0 & 2 \\
\hline & Sum & 43 & 38 & 12 & 1 & 0 & 0 & 1 & 95 \\
\hline \multirow[t]{7}{*}{ Case 4} & under 5 years & 4 & 12 & 6 & 0 & 0 & 0 & 0 & 22 \\
\hline & 6 to 10 years & 3 & 15 & 7 & 3 & 0 & 0 & 0 & 28 \\
\hline & 11 to 15 years & 4 & 11 & 6 & 1 & 0 & 0 & 0 & 22 \\
\hline & 16 to 20 years & 1 & 4 & 4 & 3 & 0 & 1 & 1 & 14 \\
\hline & over 21 years & 1 & 1 & 4 & 1 & 0 & 0 & 0 & 7 \\
\hline & not mentioned & 0 & 0 & 2 & 0 & 0 & 0 & 0 & 2 \\
\hline & Sum & 13 & 43 & 29 & 8 & 0 & 1 & 1 & 95 \\
\hline
\end{tabular}

咬合所見の診断名は, Angle の分類や高橋の 分類などに従って一義的に選択されると考えられ， 口腔外科医も矯正歯科医もほぼ同様の診断名が挙 ゲられていた。

臨床診断名にみられた顔面形態および咬合所見 の認知と, 診断者の経験年数に関連があるか検討 してみた。Table 10 は診断者の階層別経験年数 と診断名数との関係を表にまとめたものである。 各階層における診断者名数に差があるため, 診断 名数を単純に比較することはできないが，各階層 間で診断名数の分布に明瞭な差はみられなかった。
つまり，経験年数が多いほど診断名が多いとは言 えず，臨床経験と診断名数に関連性はなかった。 しかし, 顎変形症を顎顔面骨格の形態異常に不正 咬合を合併した症候群と扱うとするなら，不正咬 合の症候名は骨格異常を表す用語に包含され，診 断名には挙がってこない。また症例 3 のように, 中顔面の陥凹感が認知されても相対的「下顎前突 症」と解釈されたり, 軽度の非対称性を認知して も「顔面非対称」を診断名には挙げない診断者も あると思われ，そのため臨床経験の長短と診断名 数の間に関連性がみられなかったと考えられる 
(Table 10)。

以上をまとめると，顔面形態の診断に扔いては， 側貌における下顔面部の突出度がもっとも注目さ れる傾向にあり，正貌の非対称性や顔面高さの異 常が診断名に挙げられるのは, 明らかな非対称や 長顔あるいは短顔を呈する症例であろうと考えら れる。しかし, 顎変形症の治療では, 顔面骨格と 咬合の改善と同時に, 顔貌の審美的改善を考慮す ることが不可欠であるため, 顔面形態の臨床診断 を再考する必要があると思われた。

\section{結 論}

1）顎変形症の臨床診断名に使用された用語は, (1)総称を表す用語, (2)上顎・下顎の前突度を表す 用語, (3)正面顔貌の対称・非対称を表す用語, (4) 顔面高さの異常を表す用語, (5)咬合所見を表す用 語，(6)その他の用語に分類された。

2）同一患者に対して，診断者により異なる用 語が使用されているので, 共通の診断用語が必要 である。

3）顔面形態の診断に扔いては，下顔面の前突 度が注視される傾向にあり, 正貌の非対称や顔面 高さの異常が認知されるのは, 明らかな非対称や 高さの異常を示す症例に限定される。
本論文の要旨は, 第 7 回日本頻変形症学会総会 (平成 9 年 6 月 23 日, 於東京国際フォーラム) のイブニングフ オーラム “䫑変形症患者の形態診断一共通の臨床診断を 得るために一”の中で講演された。

本アンケート調查に回答いただきました先生方に，こ の場を借りて厚く捄礼申し上げます。また，電子メール での画像ファイルの作成ならびに送信について，丁寧に 御指導をいただきました福岡歯科大学内科学講座助教授 今村光秀先生に深謝申し上げます。

\section{文献}

1）橋本賢二，他：顎変形症の分類（診断表記法）試案. 一第 1 報顔貌軟組織形態について一, 日口外誌 31 : 2551-2555, 1985.

2）久保誼修, 他 : 顎 ・ 顔面変形症の顔面形態評価の試 み. 日頡変形誌 $6: 76-82,1996$.

3） H. L. Obwegeser：䭭変形症のための記述的用語. 日顎変形誌 $5:$ 125-129， 1995.

4）升井一朗, 他：顔面形態分類チャートによる 顎顔面 形態診断. 日顎変形誌 $6: 162-169,1996$.

5）中村康宏, 他 : 頢変形症の分類（診断表記法）橋本 試案の評価一第 1 報術前顔貌の 評価一。 日顎変形誌 $4: 37-41,1994$.

6）飯塚忠彦 : 顎変形症学会イブニングフォーラム 開催 にあたって、第 7 回日本顎変形症学会イブニングフ オーラム「䫟変形症患者の形態診断一共通の 臨床診 断を得るために一」リーフレット：1，1997. 